\title{
COMPARISON OF THE EFFICACY OF LOSARTAN, HYDROCORTISONE AND ACETYLSALICYLIC ACID (ASA) IN PREVENTING THE DEVELOPMENT OF FIBROUS SCAR TISSUE IN SKELETAL MUSCLE
}

\author{
COMPARAÇÃO DA EFICÁCIA DE LOSARTANA, HIDROCORTISONA EÁCIDO ACETILSALICÍLICO (AAS) NA \\ PREVENÇÃO DO DESENVOLVIMENTO DE TECIDO CICATRICIAL FIBROSO NOS MÚSCULOS ESQUELÉTICOS
}

\author{
COMPARACIÓN DE LA EFICACIA DE LOSARTÁN, HIDROCORTISONA YÁCIDO ACETILSALICÍLICO (AAS) EN LA \\ PREVENCIÓN DEL DESARROLLO DE TEJIDO CICATRICIAL FIBROSO EN LOS MÚSCULOS ESQUELÉTICOS
}

\author{
Otavio Melo-Silva Junior \\ (Physician) \\ Cristiana Buzelin Nunes ${ }^{2}$ \\ (Physician) \\ Tchalton Amador Corrêa ${ }^{3}$ \\ (Physician) \\ Marilia F. Silva ${ }^{3}$ \\ (Physician) \\ Laurice B. Freitas ${ }^{3}$ \\ (Physician) \\ Luiz Ronaldo Alberti ${ }^{2}$ \\ (Physician)
}

\section{Faculdade de Ciências Médicas de Minas Gerais, MG, Brazil. 2. Universidade Federal de Minas Gerais, Belo Horizonte, MG, Brazil. 3. Universidade Federal de Ouro Preto, Ouro Preto, MG, Brazil.}

\section{Correspondence:}

Otávio de Melo-Silva Júnior Rua Gonçalves Dias, 89, Sala 602. Belo Horizonte, MG, Brazil. 30.140-090. contato@otaviomelo.com.br

\begin{abstract}
Objective: To analyze fibrous scar tissue inhibition capacity with the use of losartan, hydrocortisone and acetylsalicylic acid. Method: The sample consisted of 120 male heterogeneic Wistar rats with a muscle laceration model. The rats were divided into four groups of 30 animals each: control group, losartan group, ASA group and hydrocortisone group. The animals were anesthetized and a $2.5 \mathrm{~cm}$ longitudinal incision was made in the left thoracolumbar paravertebral region. The muscles were subjected to a Grade III lesion caused by applying Kelly hemostatic forceps for 60 seconds, followed by sectioning with scissors. The skin was sutured with 3-0 nylon monofilament thread. The animals were placed in individual cages with plenty of food and water. The losartan group received losartan diluted in water at a dose of $0.1 \mathrm{mg} / \mathrm{mL}(10 \mathrm{mg} / \mathrm{kg} /$ day), the ASA Group received a 3 $\mathrm{mg} / \mathrm{mL}$ ASA solution (300 mg/ $\mathrm{kg} /$ day), and the hydrocortisone group received a $0.2 \mathrm{mg} / \mathrm{mL}$ hydrocortisone solution (20 mg/kg/day). Results: The control, losartan, hydrocortisone and aspirin groups had a fibrotic area of $0.95 \pm 0.35 \mathrm{~mm}, 0.55 \pm 0.34 \mathrm{~mm}, 0.93 \pm 0.33 \mathrm{~mm}$, and $0.66 \pm 0.36 \mathrm{~mm}$, respectively. We observed a significantly smaller fibrotic area in the losartan group compared to the control $(\mathrm{p}=0.01)$ and hydrocortisone $(\mathrm{p}=0.01)$ groups. There were no significant differences among the other groups. Conclusion: The healing of striated skeletal muscle produced less fibrous scar tissue when exposed to losartan in comparison to the control group or the hydrocortisone group. Level of Evidence l; Randomized double-blind placebo-controlled study.
\end{abstract}

Keywords: Regeneration; Transforming growth factor beta; Losartan; Satellite cells, skeletal muscle; Muscle, striated.

\section{RESUMO}

Objetivo: Analisar a capacidade de inibição de formação de tecido cicatricial fibroso com losartana, hidrocortisona e AAS. Métodos: A amostra consistiu em 120 ratos Wistar heterogênicos machos com modelo de laceração muscular. Os ratos foram distribuídos em quatro grupos de 30 animais: grupo controle, grupo losartana, grupo AAS e grupo hidrocortisona. Os animais foram anestesiados e submetidos a uma incisão em sentido longitudinal de 2,5 cm de extensão na região paravertebral toracolombar esquerda, e os músculos sofreram uma lesão grau III com pinça hemostática de Kelly durante 60 segundos e posterior secção com tesoura. A pele foi suturada com nylon monofilamentar 3-0. Os animais foram colocados em gaiolas individuais, com água e alimento à vontade. O grupo losartana recebeu losartana diluída em água na dose de $0,1 \mathrm{mg} / \mathrm{ml}$ (10 mg/kg/dia), o grupo AAS recebeu solução de AAS $3 \mathrm{mg} / \mathrm{ml}$ (300 mg/kg/dia), o grupo hidrocortisona recebeu solução de hidrocortisona 0,2 mg/ml (20 mg/kg/ dia). Resultados: Os grupos controle, losartana, hidrocortisona e AAS apresentaram área fibrótica de0,95 $\pm 0,35 \mathrm{~mm}$, $0,55 \pm 0,34 \mathrm{~mm}, 0,93 \pm 0,33 \mathrm{~mm}, 0,66 \pm 0,36 \mathrm{~mm}$, respectivamente. Observou-se área fibrótica significativamente menor do grupo losartana em comparação com o grupo controle $(p=0,01)$ e hidrocortisona $(p=0,01)$. Nos demais grupos não houve diferença significativa. Conclusão: A cicatrização do músculo estriado esquelético produziu menos tecido cicatricial fibroso quando exposto à losartana do que quando comparado com o grupo controle ou o grupo hidrocortisona. Nível de Evidência l; Estudo duplo-cego randomizado controlado por placebo.

Descritores: Regeneração; Fator de crescimento transformador beta; Losartan; Células satélites de músculo esquelético; Músculo estriado.

\section{RESUMEN}

Objetivo: Analizar la capacidad de inhibición de formación de tejido cicatricial fibroso con losartán, hidrocortisona y AAS (ácido acetilsalicílico). Métodos: La muestra consistió en 120 ratas Wistar heterogéneas machos con modelo de laceración muscular. Las ratas fueron distribuidas en cuatro grupos de 30 animales: grupo control; grupo losartán; grupo AAS y grupo hidrocortisona. Los animales fueron anestesiados y sometidos a una incisión longitudinal de 2,5 cm de extensión en la región paravertebral toracolumbar izquierda y los músculos sufrieron una lesión de grado Ill con pinza hemostática de Kelly durante 
60 segundos y posterior sección con tijera. La piel se suturó con monofilamento de nylon 3-0. Los animales fueron dispuestos en jaulas individuales con abundante comida y agua. El grupo losartán recibió losartán diluido en agua a una dosis de 0,1 mg/ml (10 mg/kg/día), el grupo AAS recibió solución de AAS de $3 \mathrm{mg} / \mathrm{ml}$ (dosis $300 \mathrm{mg} / \mathrm{kg} /$ día), el grupo hidrocortisona recibió solución hidrocortisona de 0,2 mg/ml (20 mg/kg/día). Resultados: Los grupos control, losartán, hidrocortisona y AAS mostraron área fibrótica de 0,95 $\pm 0,35 \mathrm{~mm}, 0,55 \pm 0,34 \mathrm{~mm}, 0,93 \pm 0,33 \mathrm{~mm}, 0,66 \pm 0,36 \mathrm{~mm}$, respectivamente. Se observó área fibrótica significativamente menor del grupo losartán en comparación con el grupo control $(p=0,01)$ e hidrocortisona ( $p$ $=0,01$ ). En los demás grupos no hubo diferencias significativas. Conclusión: La cicatrización del músculo estriado esquelético produjo menos tejido cicatricial fibroso cuando fue expuesto a losartán que cuando fue comparado con el grupo control o el grupo hidrocortisona. Nivel de Evidencia l; Estudio doble ciego aleatorio controlado por placebo.

Descriptores: Regeneración; Factor de crecimiento transformador beta; Losartán; Células satélite de músculo esquelético; Músculo estriado.

\section{INTRODUCTION}

Skeletal muscle lesions are responsible for a large number of complaints in orthopedic patients; for example, those with pain after intensive efforts and sports practices, and in victims of low- and high-energy impact accidents. The regenerative capacity of injured striated skeletal muscle is limited, and its natural history evolves, such as in the myocardium, with the formation of fibrotic scarring, which replaces muscle tissue. As a consequence, the number of muscle fibers is reduced after injury, and contractile function is reduced. Thus, the development of fibrosis within tissue leads to a loss of strength and muscular endurance; therefore, when an individual is subsequently exposed to new muscle stretching or trauma, new lesions may occur more readily, reinitiating the healing process, and perpetuating the presence of the lesion. ${ }^{1}$

The formation of fibrous tissue is the end result of any healing process, and predisposes skeletal muscle to recurrent lesions, thus limiting functional recovery. Healing is based on a complex sequence of events, from the initial trauma to the repair of injured tissue. Inflammation and collagen synthesis by fibroblasts are important events in the healing process. This process is crucial for tissue repair, since collagen is the main component of the extracellular matrix. Reduced production of scar tissue (fibrosis) and stimulation of muscle fiber regeneration after an injury can lead to maintained contractility after injury, preventing functional loss and accelerating rehabilitation?2.

The muscle healing process is influenced by transformation growth factor $\beta$ (TGF $\beta$ ), which is inhibited by angiotensin II receptor blockers (ARB), such as losartan. The mechanism of losartan action has been well documented in several studies, and in the clinic treatment of cardiology, nephrology, and endocrinology disorders. However, there is insufficient evidence to support its use in orthopedic practice, ${ }^{3,4}$

Some antifibrotic drugs, such as suramin, inhibit the development of fibrosis in skeletal muscle; however, their widespread use in clinical practice is limited by high costs and side effects. Although hydrocortisone inhibits inflammation and thereby limits the development of fibrosis, it has known side effects. Losartan is a widely used, low-cost, and easily accessible drug, with few known side effects, which promotes adherence to treatment. Thus, the objective of this study was to analyze and compare the development of fibrous scar tissue in animals treated with losartan, hydrocortisone, and acetylsalicylic acid (ASA).

\section{MATERIALS AND METHODS}

The legal and ethical aspects of this study followed Laws 11.794 of October 8, 2008; № 6.638 of May 08, 1979, and Decree № 24.645 of July 10,1934 , which regulate procedures associated with the scientific use of animals, and the Ethical Principles for the Use of Experimental Animals. The research protocol was evaluated and approved by the Ethics
Committee on Animal Use (CEUA), under protocol number 36/2015. The study sample consisted of 120 heterogenic adult male Wistar rats, with an average weight of $250 \mathrm{~g}$, distributed in four groups of 30 animals each (control group [CG], losartan group [LG], acetylsalicylic acid group $[\mathrm{ASA}]$, hydrocortisone group $[\mathrm{HG}])$.

The animals were anesthetized with intramuscular injections into the gluteal region with a solution of $5 \%$ ketamine hydrochloride at a dose of $35 \mathrm{mg} / \mathrm{kg}$, and $2 \%$ xylazine hydrochloride at a dose of 5 $\mathrm{mg} / \mathrm{kg}$. Following trichotomy of the whole dorsum and antisepsis, a longitudinal $2.5 \mathrm{~cm}$ incision was made in the left thoracolumbar paravertebral region. The left paravertebral muscles were pinched with Kelly hemostatic tweezers for 60 seconds, and then sectioned with scissors. The skin was sutured with monofilament nylon 3-0. The animals were monitored clinically and randomly distributed in cages following recovery from anesthesia. The animals were observed for 4 weeks to confirm their adaptation and health status (appearance of fur, activity, and weight gain). The rats received food and water ad libitum. The control group received filtered water (placebo). The losartan group received losartan diluted in water to a dose of $0.1 \mathrm{mg} /$ $\mathrm{mL}$ (10 mg/kg/day) as described by Kobayashi et al ${ }^{5}$. The ASA group received ASA $3 \mathrm{mg} / \mathrm{mL}$ (300 mg/kg/day), as described by Assy et al. (1). The hydrocortisone group received hydrocortisone $0.2 \mathrm{mg} / \mathrm{mL}$ (20 $\mathrm{mg} / \mathrm{kg} /$ day) as described by Zhu et al. ${ }^{6}$. After a 28-day observation period, the animals were anesthetized individually with a lethal dose of $\mathrm{CO}_{2}$ in a gas chamber, following loss of the corneal-eyelid reflex. The paravertebral muscle was removed and fixed in 10\% formaldehyde solution and sent to the histology laboratory. The slides were randomly numbered, and digitized photographic images were obtained under a microscope from the pathology laboratory. Images were evaluated using Panoramic Viewer software (3DHistec, Hungary), and the thickness of the fibrotic tissue was determined at the thickest point of the lesion. A single, treatment-blinded pathologist measured the width of the fibrotic region and recorded the data on a worksheet for later analysis and treatment group identification.

The ANOVA test was used to compare fibrous tissue between groups and the Scheffé test was used to assess differences between means. A significance level of $5 \%$ was used for all statistical tests.

\section{RESULTS}

Losartan-treated animals presented the smallest mean fibrotic area compared with the other groups. There was a significant difference in mean fibrotic area following losartan treatment compared with control $(p=0.01)$ and hydrocortisone treatment $(p=0.01)$, while no significant differences were found between the other groups (Table 1, Figures 1 and 2a-d). 
Table 1. Thickness ( $\mathrm{mm}$ ) of the fibrotic region in each treatment group.

\begin{tabular}{c|c|c|c|c|c|c}
\hline & & & & \multicolumn{2}{|c|}{$\begin{array}{c}\text { 95\% Confidence } \\
\text { Interval (95\% CI) }\end{array}$} & \\
\hline Treatment & $\mathbf{N}$ & Mean & $\begin{array}{c}\text { Standard } \\
\text { Deviation }\end{array}$ & Lower Limit & Upper Limit & $\mathbf{p}$ \\
\hline Control Group & 17 & 0,95 & 0,35 & 0,77 & 1,14 & 0,01 \\
\hline Losartan & 20 & 0,55 & 0,34 & 0,39 & 0,72 & \\
\hline Hydrocortisone & 21 & 0,93 & 0,33 & 0,78 & 1,09 & \\
\hline ASA & 23 & 0,66 & 0,36 & 0,51 & 0,82 & \\
\hline
\end{tabular}

(ANOVA: $p=0.01$. Scheffé test for differences between means: control group $x$ losartan: $p=0.01$; control group $x$ hydrocortisone: $\mathrm{p}=0.99$; control group $\times \mathrm{ASA}: \mathrm{p}=0.09$; losartan $\times$ hydrocortisone: $\mathrm{p}=0.01$; losartan $\times \mathrm{ASA}: \mathrm{p}=0.81$, hydrocortisone $\mathrm{ASA}$ : $\mathrm{p}=0.11$.

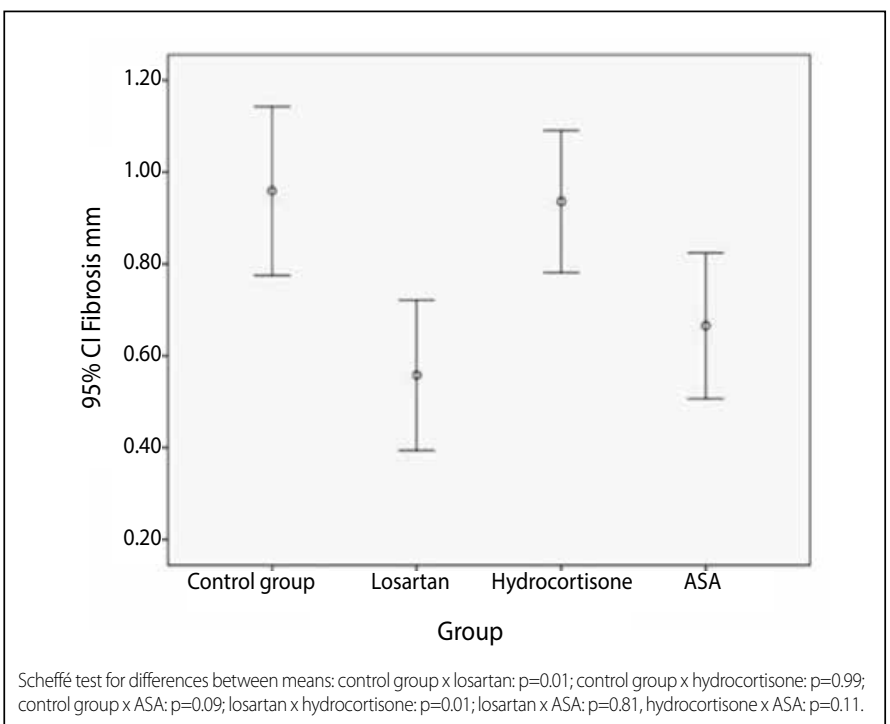

Figure 1. Distribution of the mean fibrotic area and the 95\% confidence interval $(\mathrm{Cl})$, between treatment groups.

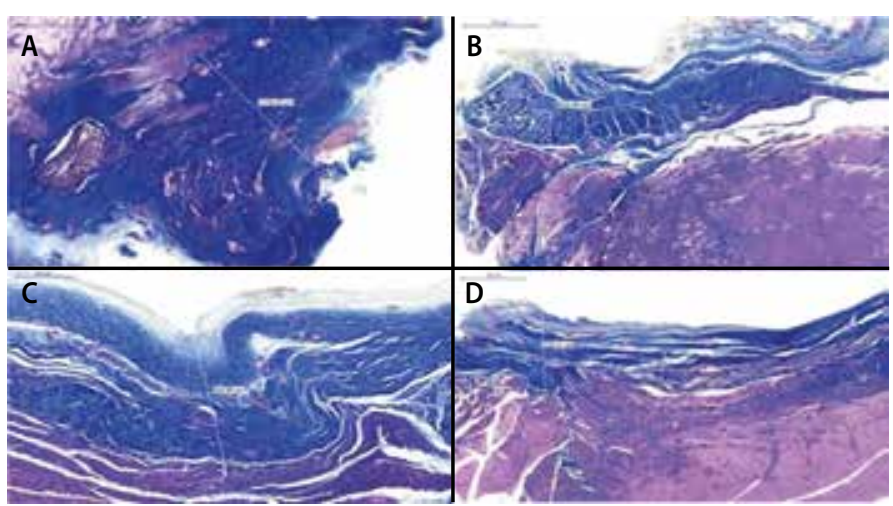

Figure 2. Histological comparison between groups. Masson's trichrome staining. (a) Control group, (b) losartan group, (c) hydrocortisone group, (d) ASA group.

\section{DISCUSSION}

Muscle lacerations were selected for this study because they represent a reproducible model for the evaluation of skeletal muscle injury. In addition, they induce substantial muscle injury, resulting in the sectioning of myofibers.

The effect of the treatment proposed in this lesion model would be at least as beneficial in less serious and more common muscle injuries, such as partial stretching or effort injuries. Scenarios of daily treatment would be better reproduced under conditions where the animals were not pretreated with medication prior to injury, as the preconditions would not sustain any bias of treatment variables.

Muscle repair following injury begins with inflammation, characterized by the presence of edema, hematoma, fibrin exudates, and the infiltration of inflammatory cells. The first cells to invade the lesion (within the first 6 hours after trauma) are neutrophils, which release cytokines (bradykinins, prostaglandins, and histamine) capable of attracting and activating additional inflammatory cells. Thus, vasodilation and increased vascular permeability occur. Macrophages are observed from 6 hours after injury, and phagocytose damaged fibers. After the first 24 hours of injury, macrophages are the main cell type present, and are responsible for the release of growth factors in the tissue. Growth factors regulate the production of satellite cells, as well as their motility and differentiation, and are responsible for activation of the $G_{0}$ to $G_{1}$ phase transition. These cells are involved in the removal of debrided material and are present in a quiescent state in the muscle tissue itself. Polymorphonuclear leukocytes rapidly accumulate at the site of the lesion, but only remain for a few hours. ${ }^{4}$

Although the model used does not accurately replicate the muscle injuries most frequently encountered in clinical practice, which are caused by contusions or lacerations, the model was chosen because it allows better standardization of the lesion in each animal, is easily implemented, and reproducible. In addition, it eliminates variables such as length, depth, and intensity of applied force when trying to induce injury by contusion or laceration, permitting better characterization of muscle healing.

Reduced residual fibrosis and increased muscle regeneration have been observed in animal models after treatment with antifibrotic drugs such as thalidomide, decorin, suramin, interferon-gamma, and relaxin. These compounds are not commonly used in clinical practice because they are costly and are associated with severe side effects, which may prevent their use in the treatment of muscle injuries. Although the clinical implications of effective therapies with antifibrotic agents are particularly important in the field of sports medicine, they apply to a larger spectrum of orthopedic patients. To date, no drug has been able to reverse established fibrosis; therefore, treatment should be applied before training. This should permit controlled regeneration, preserving muscle tissue during the initial healing phase.

Glucocorticoids and non-steroidal anti-inflammatory drugs decrease cell proliferation, neovascularization, and extracellular matrix production, which contributes to the worsening of healing.?

The results of present study showed that losartan limits the development of fibrosis in skeletal muscle lesions compared with hydrocortisone and ASA.

Losartan is a widely used drug, which is low cost and easily accessible; it is able to reduce the extent of fibrosis in different tissues, including the liver, kidneys, and myocardium, has few reported side effects and is associated with good treatment adherence. Its use to prevent fibrosis may indicate a viable alternative for the treatment of muscle injuries.

Losartan (10 mg/kg/day), administered soon after lesion induction for 3 days, increased the number of regenerated myofibers in the area of injury and exerted an antifibrotic effect in injured muscle. This was likely due to reduced TGF $\beta 1$ signaling through the blockade of AT1 receptors, inhibition of myostatin, and increased expression of endogenous follistatin. ${ }^{5}$

In a study by Goa and Wagstaff ${ }^{8}$, animals treated with losartan at $10 \mathrm{mg} / \mathrm{kg} /$ day presented decreased collagen production, and consequently, reduced myocardial fibrosis. In a study conducted by Silva ${ }^{9}$, losartan treatment in dogs with muscular dystrophy resulted in a significant decrease in TGF $\beta 1$ before and after treatment. Of note, losartan treatment only reduces the serum levels of this cytokine to those observed in healthy individuals.

Losartan reduces the expression of type I and II TGF $\beta$ receptors in the kidney of diabetic rats, and demonstrates nephroprotective effects. In mice with spontaneous hypertension, its use normalizes collagen synthesis and reverses ventricular fibrosis, with a decrease in the synthesis of type I collagen, simultaneous stimulation of the degradation of collagen and a decrease in TGF $\beta$. Furthermore, it has been used to prevent the 
progression of lesions in rats with Duchenne muscular dystrophy, and to reduce the occurrence of pulmonary complications. It also prevents aortic aneurysms in mice with Marfan syndrome and was demonstrated to block neoplastic changes when used in the treatment of breast cancer, in tumors positive for AGTR1 gene overexpression ${ }^{10-13}$.

The administration of angiotensin II receptor blockers (ARB II) after muscle laceration in adult rats significantly decreased the development of fibrosis in histopathological studies. Such a drug may also reduce striated muscle atrophy under conditions of sarcopenia ${ }^{2,3}$.

In a recent study, Terada et al. ${ }^{14}$ demonstrated that the use of losartan together with platelet-rich plasma (PRP) is capable of improving the regeneration of the anterior tibialis muscle following contusion injury in rats. The study demonstrated that fibrosis was lower in the muscle when losartan + PRP was administered, compared with PRP alone. PRP alone is able to accelerate the healing process, but as it is rich in TGF $\beta 1$, it also increases the fibrotic index. Treatment with losartan + PRP induced angiogenesis and increased follistatin expression, an inducer of muscle growth, and inhibited the expression of TGF $\beta 1$.

Nevertheless, the use of an anti-hypertensive medication may be associated with several limitations. Thus, the doses administered to animals in the experiment were below the equivalent dose associated with the antihypertensive activity of losartan in humans; therefore, no adverse effects would be expected in animals. The long-term treatment of skeletal muscle injuries in mice with an ARB reduces the amount of fibrosis and increases the number of myofibers regenerated in the injured area. This is a time-dependent phenomenon, in which medication administered for long periods provided greater regenerative benefit.

Notably, the potential adverse effects of angiotensin II receptor antagonists are surprisingly low compared with those of other anti-hypertensive drugs. The only side effect reported is dose-dependent hypotension. Other adverse effects include headache, dizziness, weakness, and fatigue, which are not dose-dependent. Although uncommon, there have also been reports of increased liver enzymes, cholestatic hepatitis, and pancreatitis with the use of losartan.

In summary, the use of the ARB losartan, a commercially available drug, which is usually well-tolerated, safe, and widely used as an anti-hypertensive medication, may improve the healing of skeletal muscle, reduce fibrosis, and increase muscle regeneration. These findings may support a clinically attractive antifibrotic therapy for healthy individuals who have suffered acute lesions of the skeletal muscle.

However, data reported in the literature vary greatly in relation to the methodology employed; thus, the results are dependent on the type, dose of medication used, animal model studied, duration of treatment, and the methods used to evaluate the effectiveness of healing, hindering comparisons with the results of the present study.

\section{CONCLUSION}

The administration of losartan - after 28 days of treatment - significantly reduced the development of fibrosis following laceration in striated skeletal muscle of heterogenic Wistar rats, compared with the use of hydrocortisone or placebo.

\section{ACKNOWLEDGMENTS}

We thank Dr. Gastón Topol for his assistance translating the Abstract into Spanish.

All authors declare no potential conflict of interest related to this article.

AUTHORS' CONTRIBUTIONS: Each author made significant individual contributions to this manuscript. OMSJ (0000-0003-1684-4809)*: intellectual concept, preparation and planning of the study, surgical procedures, preparation of the slides, statistical analysis, writing, review and approval of the final version; TAC (0000-0002-1989-1574)* surgical procedures, data obtainment and analysis, and writing; MFS (0000-0001-7865-2840)* surgical procedures, data obtainment and analysis, and writing; LBF (0000-0003-3912-6308)* surgical procedures, data obtainment and analysis, and writing; CBN (0000-0002-5266-68) analysis of the slides, data review and writing; LRA (0000-0002-5299-3971)* intellectual concept, writing, critical review of the content and final approval. *ORCID (Open Researcher and Contributor ID).

\section{REFERENCES}

1. Assy N, Hussein O, Khalii A, Luder A, Szvalb S, Paizi M, et al. The beneficial effect of aspirin and enoxaparin on fibrosis progression and regenerative activity in a rat model of cirrhosis. Dig Dis Sci. 2007;52(5):1187-93.

2. Bedair HS, Karthikeyan T, Quintero A, Li Y, Huard J. Angiotensin II receptor blockade administered after injury improves muscle regeneration and decreases fibrosis in normal skeletal muscle. Am J Sports Med. 2008;36(8):1548-54.

3. Burks TN, Andres-Mateos E, Marx R, Mejias R, Van Erp C, Simmers JL, et al. Losartan restores skeletal muscle remodeling and protects against disuse atrophy in sarcopenia. Sci Transl Med. 2011;3(82):82ra37.

4. Ferrari RJ, Picchi LD, Botelho AP, Minamoto V. Processo de regeneração na lesão muscular: uma revisão. Fisioter Mov. 2005;18(2):63-71.

5. Kobayashi T, Shusuke O, Kenji U, Kimimasa T, Fabrisia A, Fu FH, et al. Angiotensin II receptor blocker promote muscle healing after injury through. activation of muscle regulations. In: 8th Biennial International Society of Artrhoscopy Knee Surgery and Orthopaedic Sports Medicine Congress. Rio de Janeiro, May 15-19, 2011.

6. Zhu H, Chu Y, Huo J, Chen Z, Yang L. Effect of prednisone on transforming growth factor- $\beta 1$, connective tissue growth factor, nuclear factor-kBp65 and tumor necrosis factor-a expression in a murine model of hepatic sinusoidal obstruction syndrome induced by Gynura segetum. Hepatol Res. 2011;41 (8):795-803.

7. Rosen DJ, Patel MK, Freeman K, Weiss PR. A primary protocol for the management of ear keloids: results of excision combined with intraoperative and postoperative steroid injections. Plast Reconstr Surg. 2007;120(5):1395-400
8. Goa KL, Wagstaff AJ. Losartan potassium: a review of its pharmacology, clinical efficacy and tolerability in the management of hypertension. Drugs. 1996;51(5):820-45.

9. Silva MB. O efeito do losartana na morfologia do músculo esquelético do modelo Golden Retriever Muscular Distrophy: uma droga promissora para a regeneração muscular distrófica? [dissertação]. São Paulo: Faculdade de Medicina Veterinária e Zootecnia, Universidade de São Paulo; 2009.

10. Rhodes DR, Ateeq B, Cao Q, Tomlins SA, Mehra R, Laxman B, et al. AGTR1 overexpression defines a subset of breast cancer and confers sensitivity to losartan, an AGTR1 antagonist. Proc Natl Acad Sci U SA. 2009;106(25):10284-9.

11. Varo N, Iraburu MJ, Varela M, López B, Etayo JC, Díez J. Chronic AT(1) blockade stimulates extracellular collagen type I degradation and rever myocardial fibrosis in spontaneously hypertensive rats. Hypertension. 2000;35(6):1197-202.

12. Habashi JP, Judge DP, Holm TM, Cohn RD, Loeys BL, Cooper TK, et al. Losartan, an AT1 antagonist, prevents aortic aneurysm in a mouse model of Marfan syndrome. Science. 2006;312(5770):117-21.

13. Guo ZX, Qiu MC. [Losartan downregulates the expression of transforming growth factor beta type I and type II receptors in kidney of diabetic rat]. Zhonghua Nei Ke Za Zhi. 2003;42(6):403-8.

14. Terada S, Ota S, Kobayashi M, Kobayashi T, Mifune $Y$, Takayama K, et al. Use of an antifibrotic agent improves the effect of platelet-rich plasma on muscle healing after injury. J Bone Joint Surg Am. 2013;95(11):980-8. 